\title{
Why photograph ballet or where ballet photographers come from
}

\author{
Andrey Stepanov [0000-0001-6291-7242]
}

Institute of Certified Specialists, Perm, Russia

$\underline{\text { https://doi.org/10.33847/2712-8148.1.1_5 }}$

\begin{abstract}
This paper focuses on the topic of ballet photography. An attempt was made to analyse the ratings of ballet photographers and title the most famous names. Ballet photography and possible paths for ballet photographers are discussed. In my reasoning, I took into account my example and experience. The article draws a simple and clear conclusion about who is interested in ballet photography and about the role of ballet photography in modern period.
\end{abstract}

Keywords: ballet, ballet photographer, photography

\section{Ballet photography - who is who}

The world of ballet photography is rather small and closed. Not so many famous photographers who have dedicated their work only to this topic. However, some famous masters of photography who have worked in others directions, also touched ballet and left here their noticeable track. The list of some names titled in the publication of La Personne Magazine "To catch the air into the lens ..." [1]. Among them are such famous names as Richard Avedon, Annie Leibowitz, Karl Lagerfeld, Patrick Demarchelier, Peter Lindbergh and some others.

There is also a rating of Ballet 24 Magazine - there are also enough names. In addition, there are names that not mentioned in these lists and ratings, but deserve to be name too.

Some of the photographers took pictures of ballet dancers only on-stage during performances, someone dedicated their work to specific topics in ballet that worried and affected them, someone shot projects for magazines and companies, carried out orders from theatres, and someone lined up beautiful and almost architectural compositions in front of his own camera and shot outstanding staged shots. Everyone saw and showed ballet in their own way, but everyone talked about ballet.

According to the Ballet 24 magazine [2], the list of top 5 Russian photographers includes such masters of ballet photography as Vadim Stein from St. Petersburg, Viktor Dmitriev from Novosibirsk, Mark Olich, Oleg Zotov and Daryan Volkova, the last three from St. Petersburg too. Each of them has their own style and their own vision of ballet. By the way, I am glad for my short acquaintance with one of them. We met with Mark Olich thanks to Diana Vishneva's Context Festival, and then met in person on the shooting of the performance staged by Lera Taglioni. I think Mark is a very interesting photographer, whose style cannot be confused with anyone else.

According to the Ballet 24 magazine top-5 foreign ballet photographers [3] consists of the following names - Taylor-Ferne Morris (from Melbourne, Australia), Rick Guest (from UK), Carlos Quezada (from Germany), Rachel Neville (from New York), Luis Pons (from New York).

La Personne magazine has its own top list [1] - perhaps it contains all the most famous photographers - Arthur Elgort, Mario Testino, Irving Penn, Richard Avedon, Tim Walker, Annie Leibovitz, Karl Lagerfeld, Patrick Demarchelier, James Bort, Yan Omelnitsky, Henry Leutwyler, Danil Golovkin, Reuven Afanador, Ken Browar and Deborah Ory (NYC Dance Project), Lisa Rose, Peter Lindbergh.

The following names such as Alexander Yakovlev, Vladimir Sazonov, Alexey Pankov, Mikhail Logvinov, Valery Logachev, Elena Pushkina, Natalia Voronova, Vladimir Lupovsky also often mentioned in the press - their photos regularly published in the press and appear on social networks. I know some of the Russian photographers personally, with some of them I crossed paths in the theatre.

CICS. Journal of DIGITAL SCIENCE, Vol.1, Iss. 1, Dec 2019 
I think now it will be very self-confident to declare that I want to be in one of these lists. However, I definitely want to be somewhere near. I can qualify my work as a stage photography, for the present day, as in my current practice is dominated shooting of performances from the auditorium. Although there are other shootings in my practice - behind the scenes, for the posters, personal shooting, and there are some plans for new projects.

During the year that I have been shooting ballet, I have managed to achieve some results. I had already the opportunity to photograph the prima ballerinas of the Bolshoi Theatre [4] and of the Kremlin Ballet [5], shooting such star dancers such as Diana Vishneva [6] and Sergei Polunin [7]. I was lucky to shoot stars of different theatres in the Kremlin Palace [8] and at the ballet gala evening dedicated to Frederic Chopin [9]. I work for Kommersant Publishing House as a freelancer and have many publications in the Russian press.

I think that all the lists and ratings of ballet photographers are rather arbitrary, and are absolutely subjective, because there is not and cannot be any standard in photographic art which can be used to measure the fame of a particular photographer. However, there are certainly a number of signs by which you can judge the fame and the popularity of a particular author, for example, the number of publications and references in the press, participation in exhibitions, personal expositions and special projects for customers. I think that I have already taken the first steps in this direction.

This paper is a collection of my reflections on ballet photography. It is perhaps a little deeper analysis of how I see this world, and to what category of photographers I relate myself at the moment or want to relate in the future. And also, about people for whom ballet photography is interesting and about its role in our culture. And for whom I shoot ballet.

\section{The road to ballet photographer}

I came across a ballet photograph not so long ago. Before that, there was one very old story. Back in my student years when I was on practice in Moldova, I made my first fashion shot, which I give codenamed "Three Graces". These were three female students in bikini in the middle of the lake on a large concrete pedestal, decorated with willow branches and herbs. It was a spontaneous idea and shooting. It is just that at that moment we were preparing to shoot our own film, but our idea collapsed because of two friends. After this accident, there was a desire to do something, and I came up with this photo session and made this frame. After that, I had a big break in fashion shooting, practically up to now. It may be pretention, but I still consider this frame a great masterpiece. The attention for this direction has remained to this day - I sometimes do fashion shooting and periodically observe fashion photographers [10]. I think that at that time it was just an unknowing desire to take photos of something beautiful. However, apparently, this desire was later transformed and grew into ballet photography. You can read about how it happened and what happened before in the Dozado Dance magazine [11-14].

At some moment, I came across a New-York Dance Project (photo project) with stunning works and photos of ballet dancers floating in the air in different beautiful poses. I was very excited about it. I wanted to shoot ballet, but I absolutely did not know how to approach it. It was some kind of inaccessible and closed world for me. The desire was very great and somehow, I told about it to one of my clients who I shot in the parks of Moscow. She told me then - "Andrey, you can do everything, you can see everything very well and you will succeed." But there was a question how to get models from the world of ballet. Then she told me that she has a relative who dances and she will tell her about me.

As a result, after some time I had my first ballet shooting. I am very grateful to my first model. I began to shoot a lot of ballet performance. I was ready to discuss the results with my clients and I was sometimes told what they would like to see as the result. It helped me a lot to move forward. 
After that, I wanted to get to the theatre and shoot on stage. I started trying to be accredited to theatres as an independent photographer. Sometimes I was able to do it, sometimes I did not. Moreover, I understood that it was very difficult to be independent and I started thinking about partnership with a publication.

Looking through the pages of various publications, I found an invitation to Kommersant Publishing House and thought why not try. It was necessary to just simply write about myself, prepare a portfolio, send it and wait. Thus, I did it. In addition, by that time I already had a portfolio that could be shown. As a result, I took a status of freelance photographer. It was a stage in my professional career, because I understood that no one was accepted into such a publication. For me, it was a milestone and another moment of self-assessment (because photographers often have very doubts about their level). It is the moment then I understand that I do not worse of many other professional photographers.

Our cooperation is still ongoing. I am glad that my ballet pictures regularly appear in Kommersant Photo Bank [4-6] in Culture section. Actually, it is always possible to buy my photos there. Sometimes it happens and I am very happy about it.

A little later, I found more partners with whom I cooperate - the magazine Window to Moscow $[8,10]$, InterMedia agency and some others.

Now I always have a choice to be accredited as an independent photographer or as a photographer, representing the media. The largest stages, such as concert Hall "Zaryadye", Kremlin Palace, Crocus City Hall and others become available for me.

Not so long ago I had my first shooting at the Bolshoi Theatre for Kommersant Publishing House. It was shooting Svetlana Zakharova and Vadim Repin open rehearsal of performance "Pas de on the fingers and for the fingers" (Photo 1-3), [4]. After that I am shooting their performance on the stage of Concert Hall of them Tchaikovsky in Moscow Philharmonic.

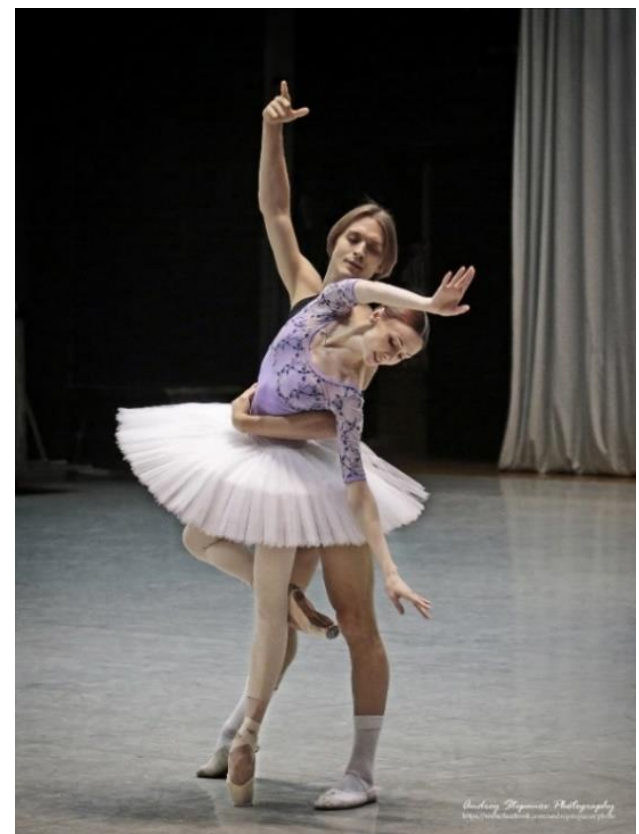

Photo1

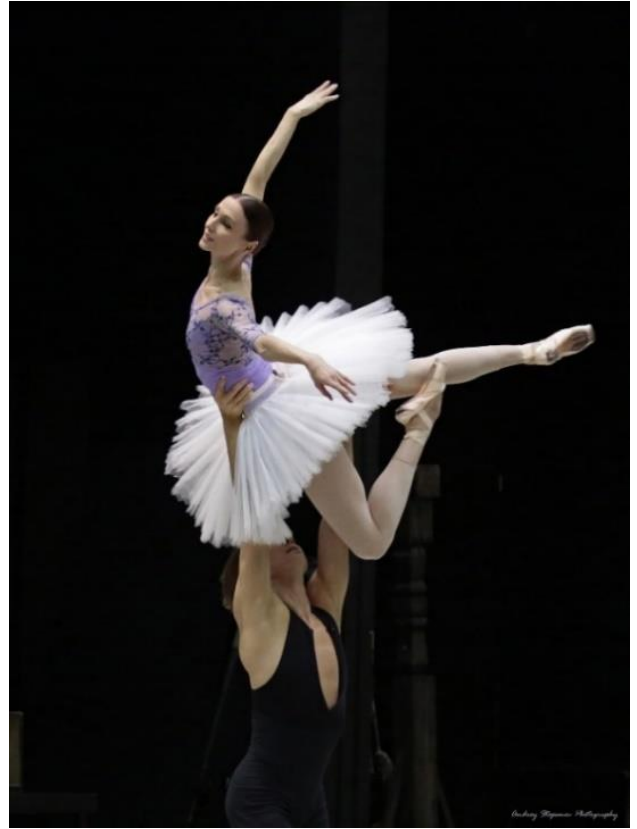

Photo 2 


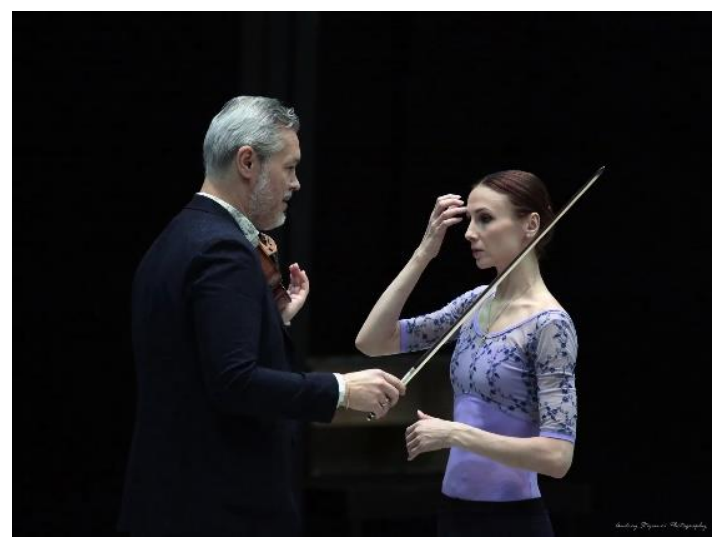

Photo 3

Now I have the next dream - to shoot specially for the Bolshoi Theatre and the Musical Theatre of Stanislavsky and Nemirovich-Danchenko, and also to go to St. Petersburg and get acquainted with the Eifman Ballet, the Mariinsky Theatre, the Mikhailovsky Theatre, the Alexandrinsky Theatre and also shoot dancers in the city.

\section{About the choice of the directions}

Now I am very interested in shooting both classical ballet and modern. I try to capture and convey all the beauty of the human body and its movements. It seems to me that it is through dance that it is possible to reveal not only the capabilities of a person, but also to convey the state of his soul.

I am interested in studying different choreography through my photos. The dance in ballet has passed a very long way of development. In addition to classical ballet, there is a modern ballet with its various directions, which are developing to this day.

It helped me a lot in this respect to be acquainted with two companies. The first one is a small modern dance company - Articuli Dance Company, the second one is an already established and proven ballet company - Ballet Moscow Theatre. However, my acquaintance with modern dance began with the Articuli Dance Company. Their first performance, which I attended and which I photographed, was at the President Hotel at the vernissage organized by Kvartira S Galleries. (Photo 4-5).

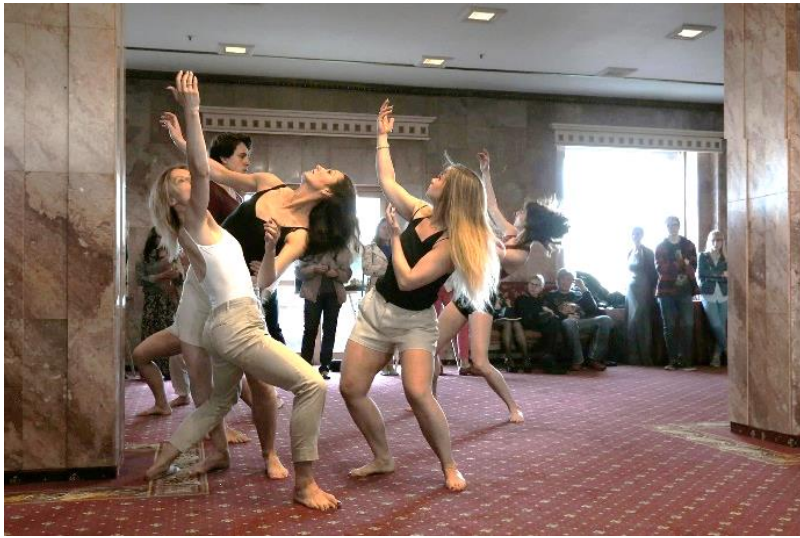

Photo 4

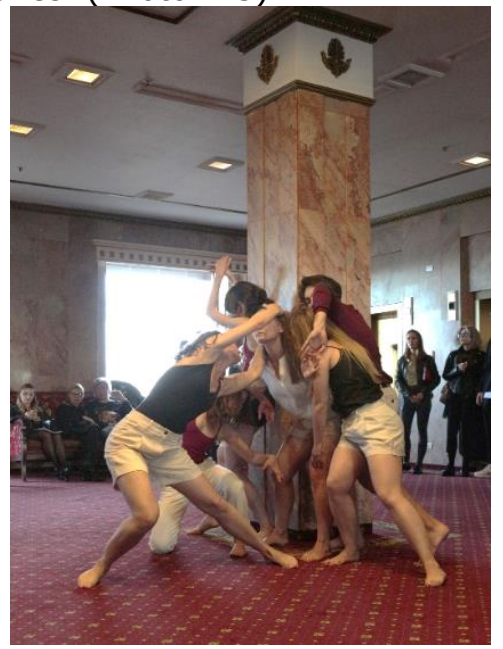

Photo 5

Then there were other shootings with this team, including in The Multimedia Art Museum on the background of the Lobster Land exhibition of the famous contemporary English artist Philip Colbert (Photo 6-7, 59). I was interested to see 
how contemporary choreography and modern arts would interact. The highest appreciation of my photographs was the positive reaction of the artist himself and the museum.

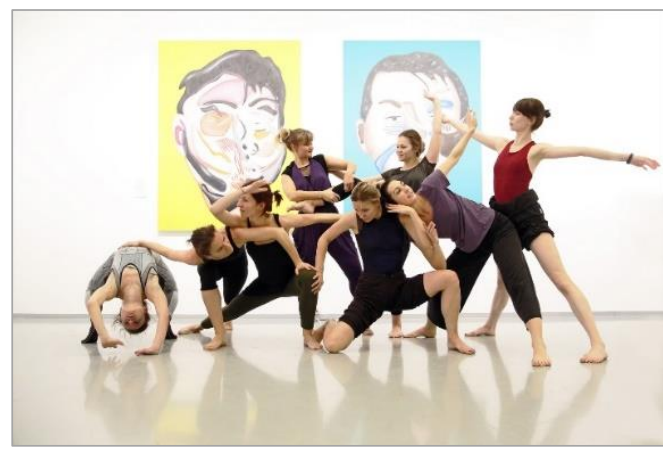

Photo 6

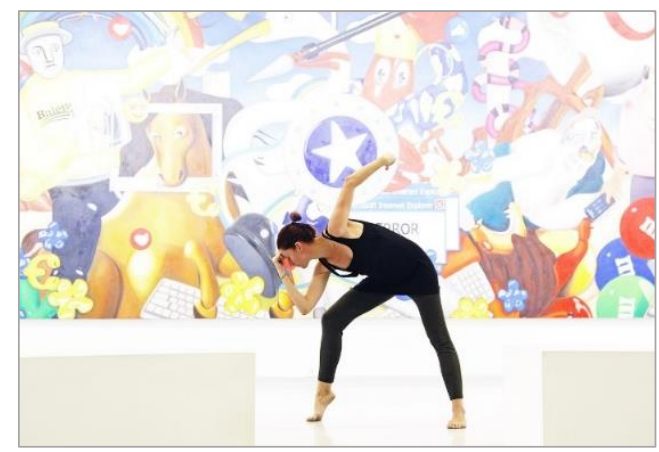

Photo 7

I keep the contacts with Articuli Dance Company and with its head and choreographer Catherine Mallinder. I am interested in watching how the choreographer develops and grows and how his young company is changing, gradually gaining its audience and fame in the choreographic world. Her style and performances do not resemble anyone. This is the most interesting thing.

The other company is Ballet Moscow. I got to know with Ballet Moscow at the Festival of actual art, which was held in the shopping centre Afimall. It was very bright literally performance - "Cafe Idiot". Artists danced in the brightest white and red suits. These are the first moments of acquaintance.

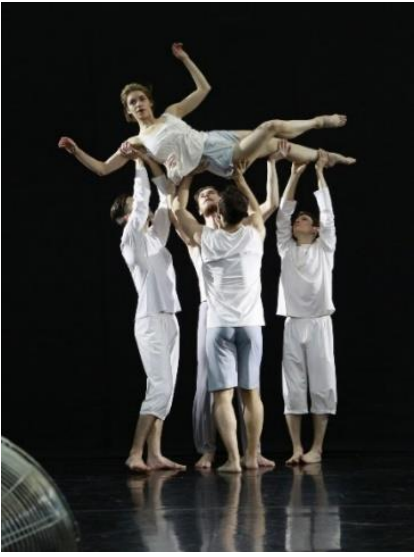

Photo 8

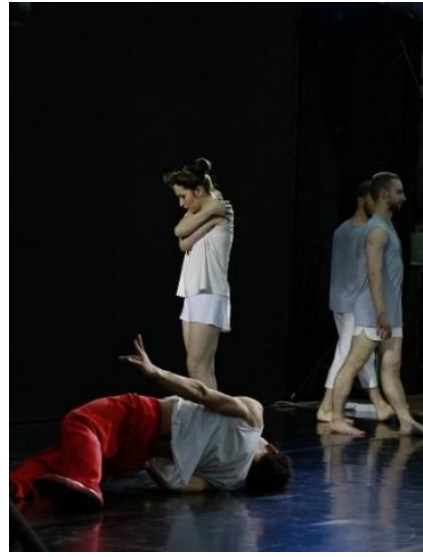

Photo 9

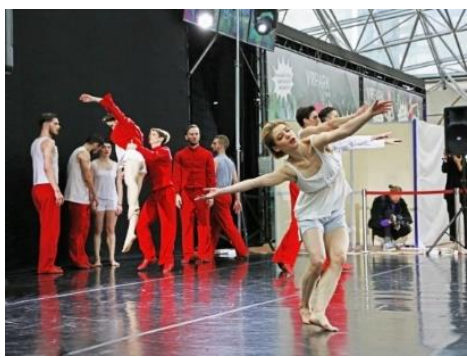

Photo 10

What did Ballet Moscow give me in terms of studying modern choreography? Probably the opportunity to see the intersection of modern ballet and classical ballet (in this case, ballet that dances on pointe). Ballet Moscow has two troupes - a modern choreography group and a classical group (now they call it just a ballet group). Although both of them dance modern ballet. In the repertoire of the ballet group, there is no Swan Lake, the Nutcracker, Sleeping Beauty, those ballets that we consider classics. However, they often dance modern choreography on pointe and from here completely different choreography than the modern group. In one of the performances, they managed to combine both troupes and both variants of choreography - this is a magnificent performance "Dance hall" (Photo 11-12). It was very interesting to see both type of choreography in one performance. 


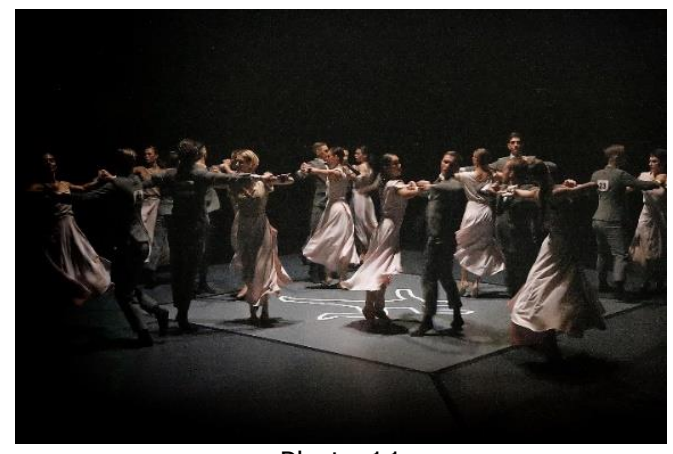

Photo 11

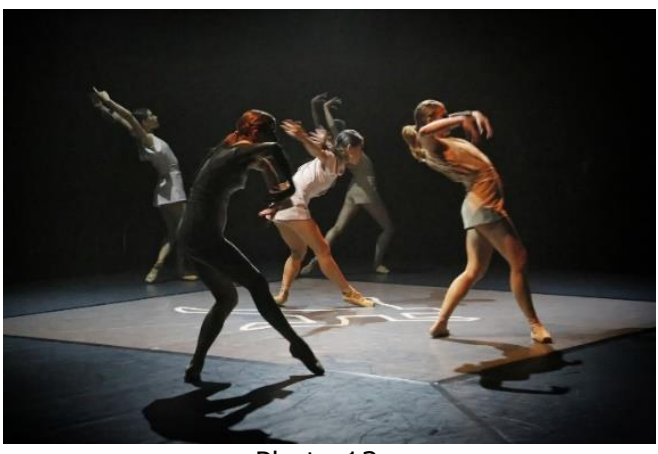

Photo 12

It is a performance filled with dynamics, grace, emotions that captures the hall and holds it from the beginning to the end. Another program of Ballet Moscow, which involves two troupes at once, is the ballets "Death and the Maiden" (Photo 13) and "Second Cast" (Photo 14) [15]. In these ballets, the troupes change places. In addition, this is the main interest, which attracts these performances.

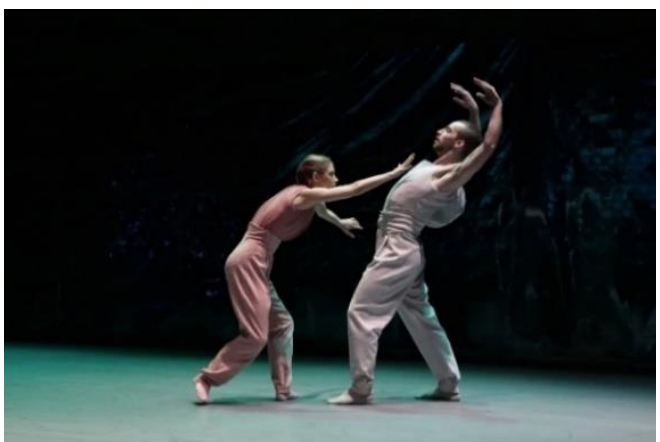

Photo 13

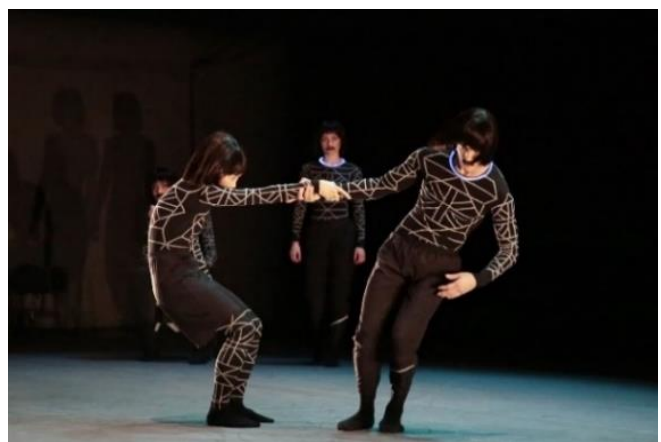

Photo 14

I had a chance to work not only in the theatre space with the Ballet Moscow, but also to photograph their performance at the Museum of Fine Arts named after A. Pushkin (Photo 15-16). In this case, it was interesting to see the possibility of interaction between modern ballet and the art of the Renaissance.

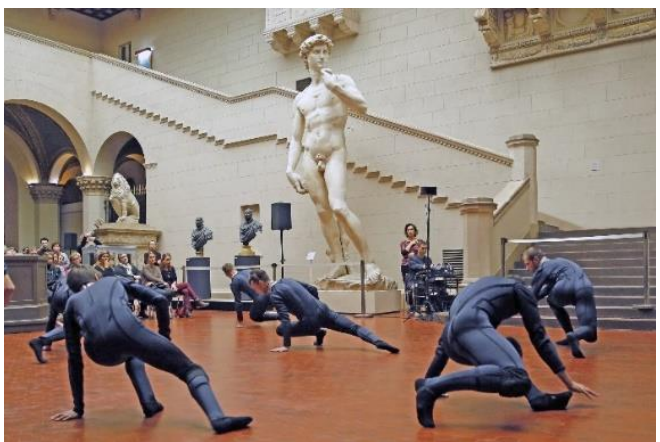

Photo 15

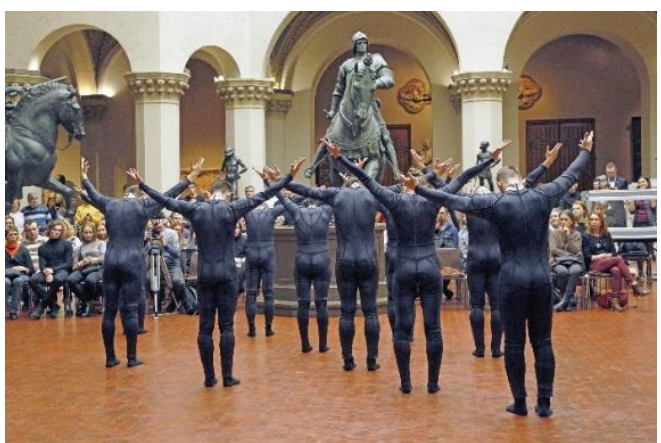

Photo 16

Another ballet I shot in the centre of Meyerhold was "Waiting for Godot mode" (Photo 17-18), which is quite interesting in terms of space and colour. 


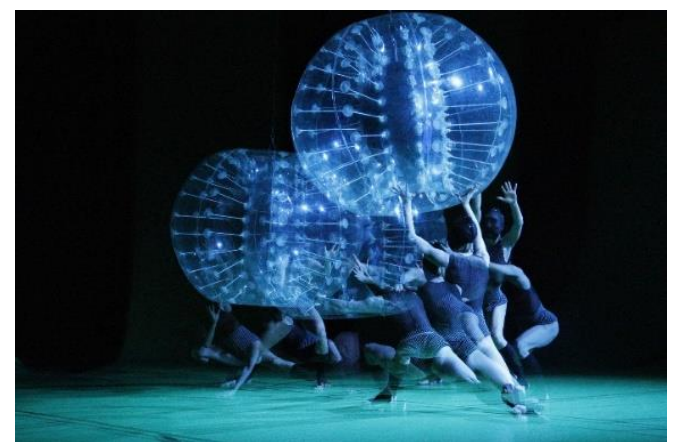

Photo 17

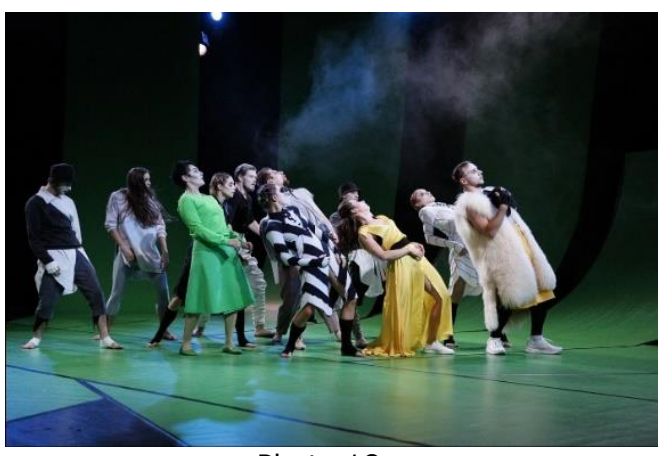

Photo 18

It was another interesting experience when Ballet Moscow performed at the Museum of Russian Impressionism, where the performance "Transcription of Colour" was shown (Photo 19-20,61). The colour scheme of the performance was very much in harmony with the works of the Impressionist artists, represented at that time in the exhibition "Impressionism and Spanish art." The stage was literally filled with bright and pastel colours.

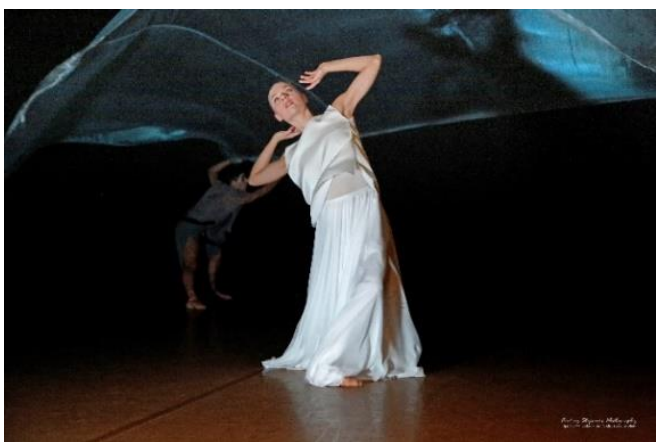

Photo 19

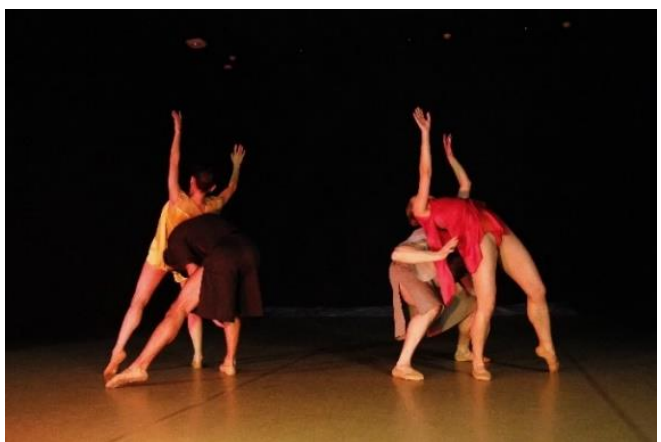

Photo 20

I have to say separately about the New Ballet Theatre and its modern ballets "Bolero" (Photo 21-22), "Carmina Burana", "Pushkin. Shot" and many others. All of them are worthy of a particular attention. Acquaintance with this theatre was kind of landmark for me, because it was the first theatre, which accredited me, as an independent photographer.

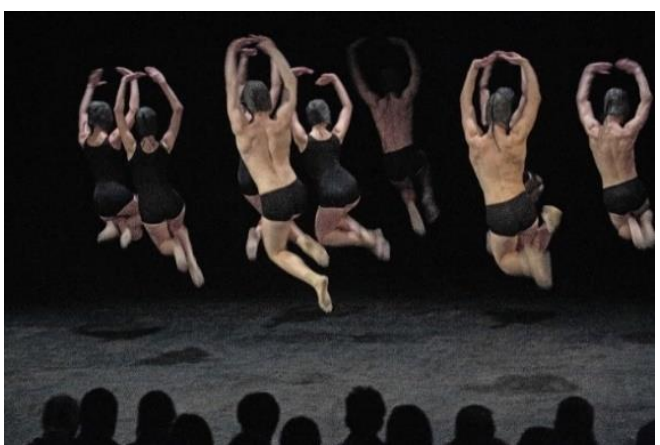

Photo 21

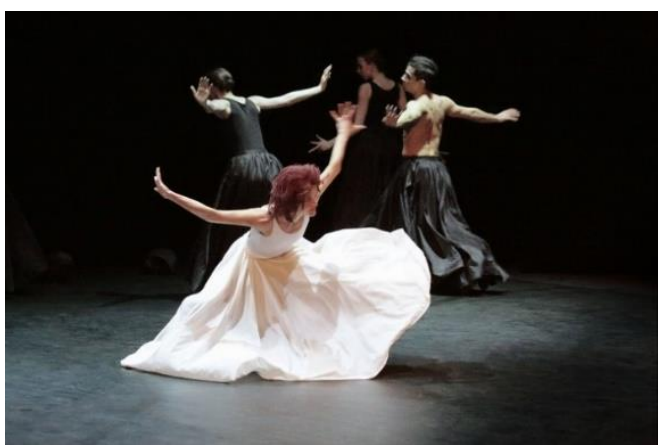

Photo 22

If speaking about modern choreography, there was other very interesting meeting with performances of different choreographers such as Hofesh Shehter with its performance "Grand finale", Edward Klug - "Sleeping Beauty Dreams" (Photo 2324) with Diana Vishneva in the main party, Anna Verde - "Russian Muse of Salvador 
Dali", Cyril Radev - "Ballad for Madman", Karin Ponties - "Every Directions is North", Yuri Smekalov - "Three Mask of the King" (Photo 25-26), plastic performance of Eugene Venin - "Accidentia" (Photo 64), Alexander Mogilev - "Ditties, your mother" and some others. Each ballet - it is own history, its own individual choreography, own style of the performance. Each of them in itself an outstanding performance. Not sure, that in the article I need to tell about them something more. I think it deserves a separate work. I will publish here only certain photos from the two performances "Sleeping Beauty Dreams" and "Three Mask of the King".

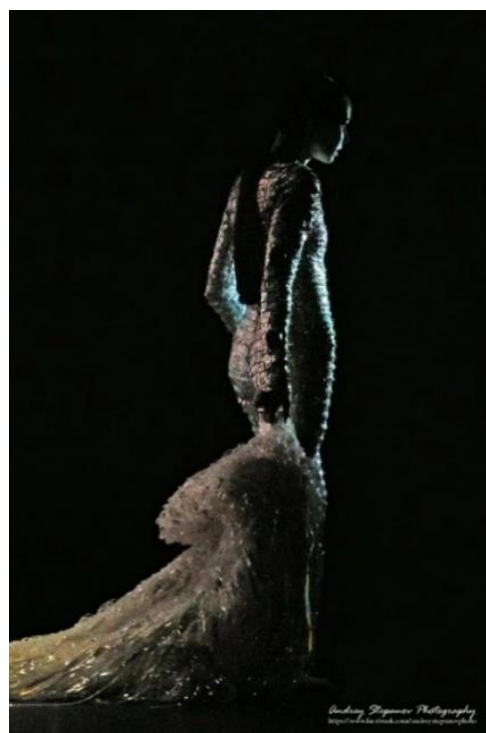

Photo 23

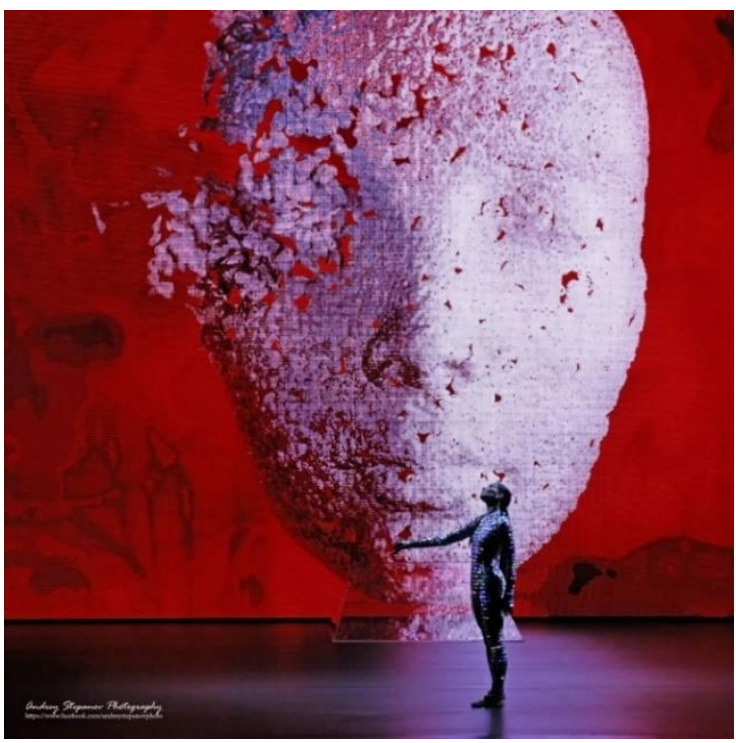

Photo 24

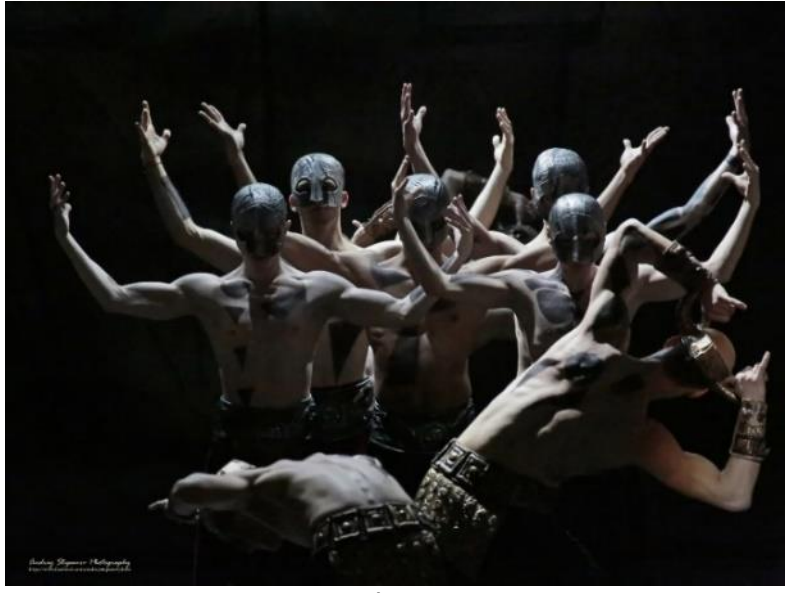

Photo 25

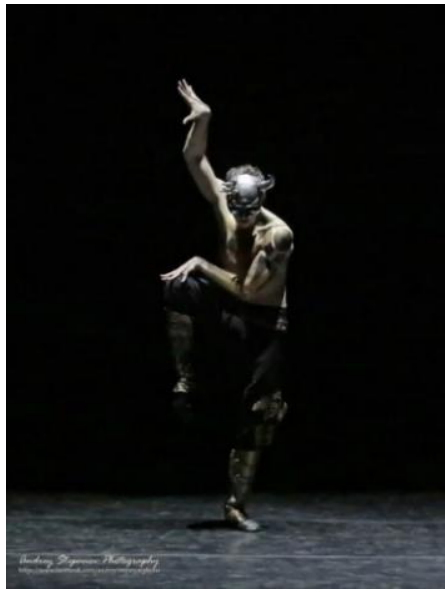

Photo 26

In addition to this list of outstanding performances, I encountered with a very wide range of modern choreography on the two festivals - Diana Vishneva Context Festival and Contest (Photo 27) and Alexander Mogilev Proba \# Festival (Photo 29$30,57,60)$. 


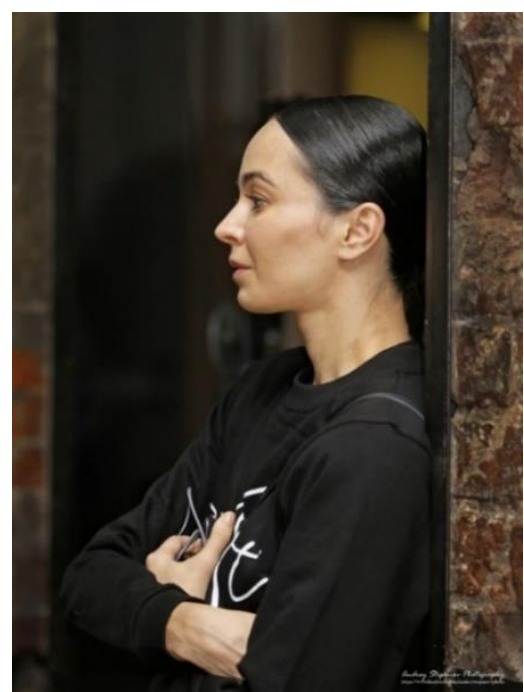

Photo 27

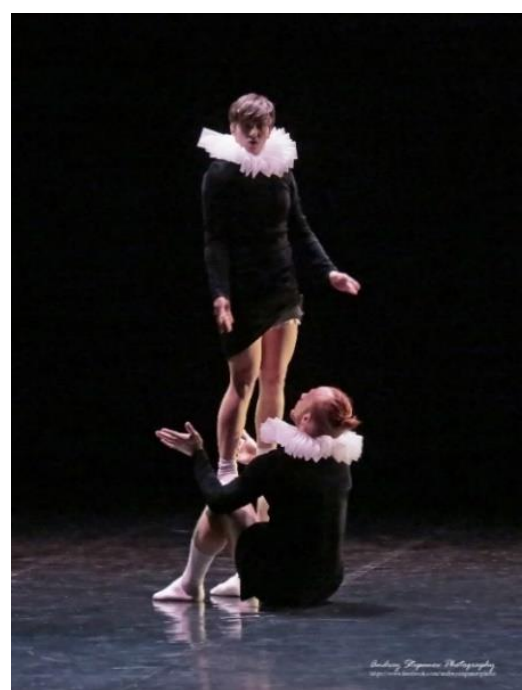

Photo 29

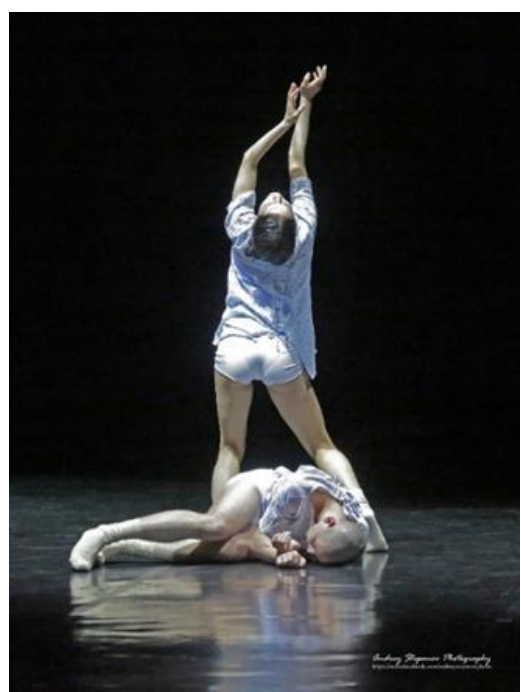

Photo 28

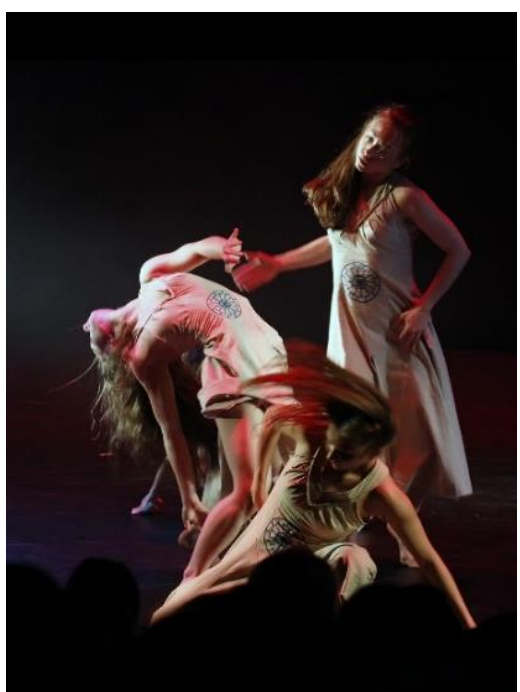

Photo 30

If speaking about the pure classical ballet, it is, of course, performances of the Kremlin Ballet - "Swan Lake" (Photo 31), "Corsair", "Romeo and Juliet" (Photo 32, 62-63) [5].

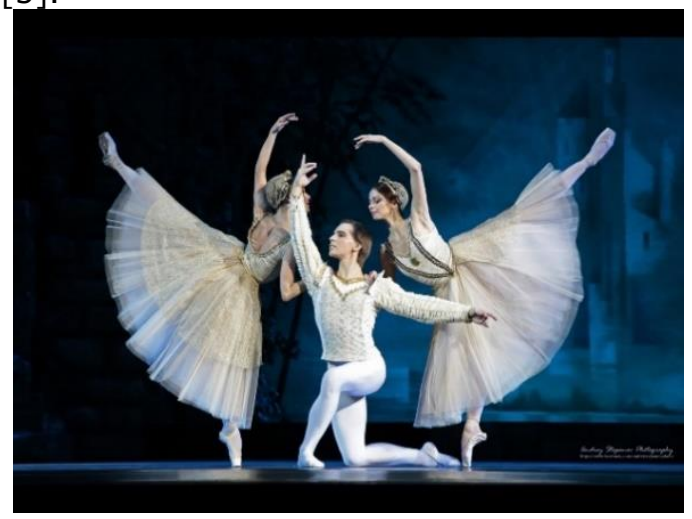

Photo 31

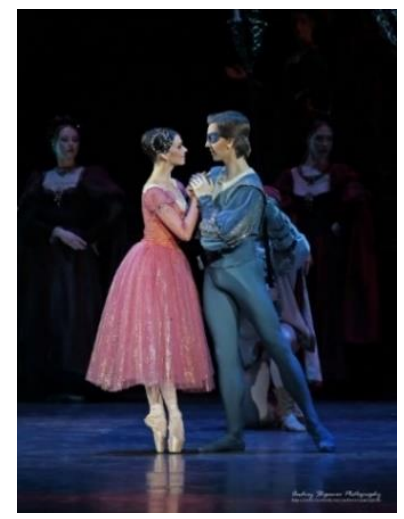

Photo 32

(C)ICS. Journal of Digital Art \& Humanities, Vol.1, Iss. 1, Oct 2020 
Here we can also add a new ballet "Little Red Riding Hood" (Photo 33-35) in the production of choreographer Ross Freddy with Sergey Polunin in the leading party. I think that the ballet "Little Red Riding Hood" [7] should be attributed to the neoclassical ballet.

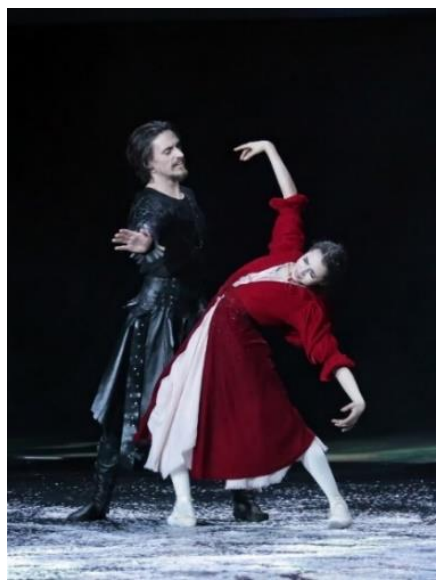

Photo 33

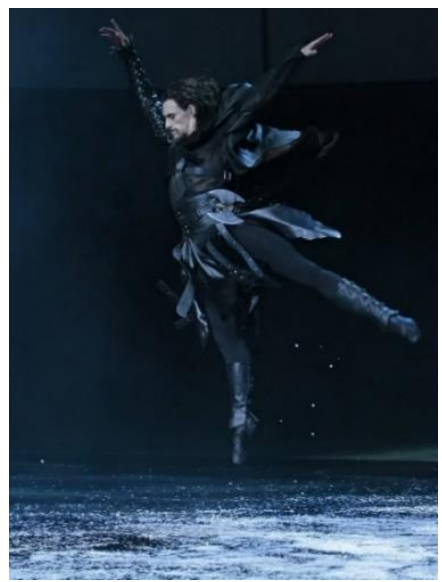

Photo 34

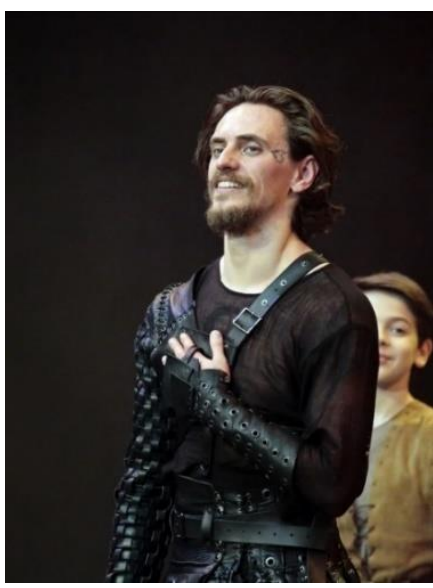

Photo 35

It is possible to include performances of the Classical Ballet Theatre leading by Natalia Kasatkina and Vladimir Vasilev to the same list - "Swan Lake", "Sleeping beauty", "The Nutcracker" and other classic performances. Separately, we can select premiere of "Cracatuk" ballet (Photo 36-37), which took place in the Bolshoi Theatre, which also not fully refer to the classics or even to the neo-classic as this ballet absorbed a lot of different choreographic areas, including classic and modern ballet.

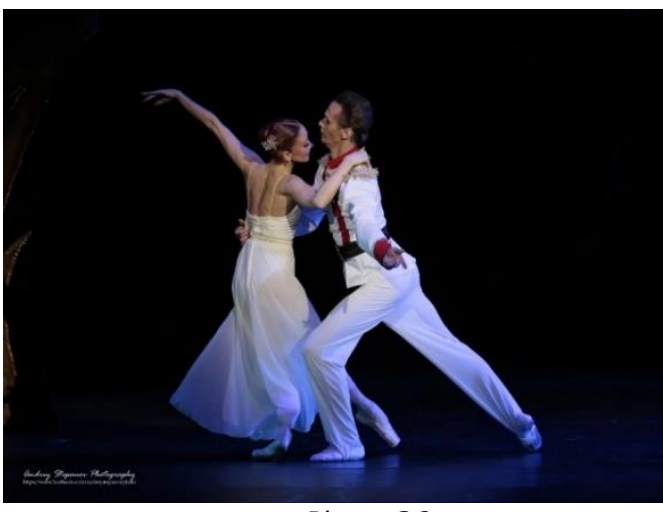

Photo 36

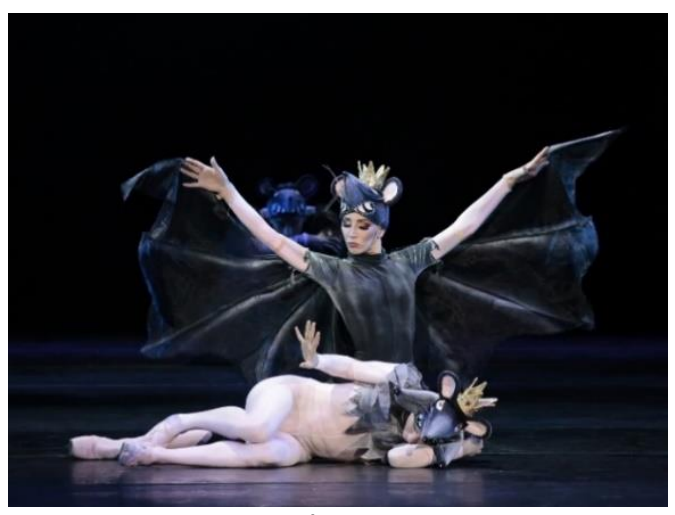

Photo 37

Ballet Gala "Maris Liepa. With love" (Photo 38-43) [8] in the Kremlin Palace gave me the opportunity to meet leading artists from the Bolshoi Theatre, Stanislavsky and Nemirovich-Danchenko Musical Theatre, Michailovsky Theatre, Mariinsky Theatre, The Kremlin Ballet and other famous theatres. 


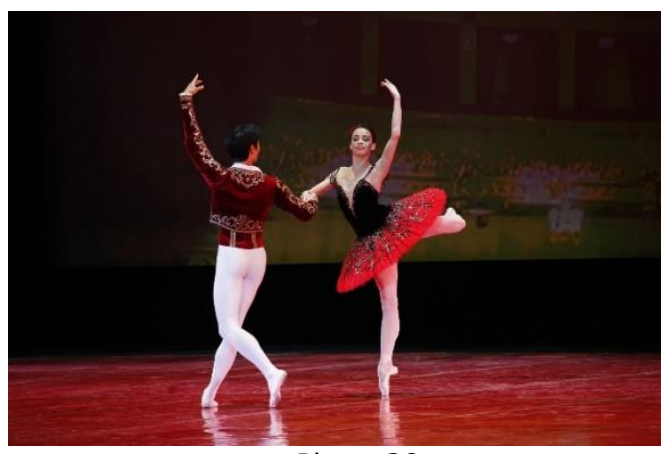

Photo 38

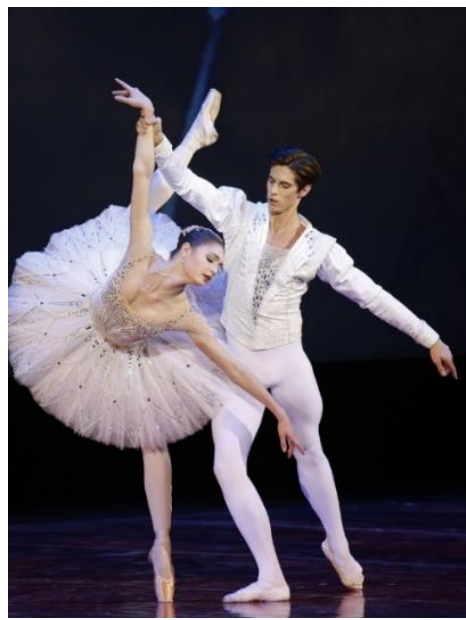

Photo 40

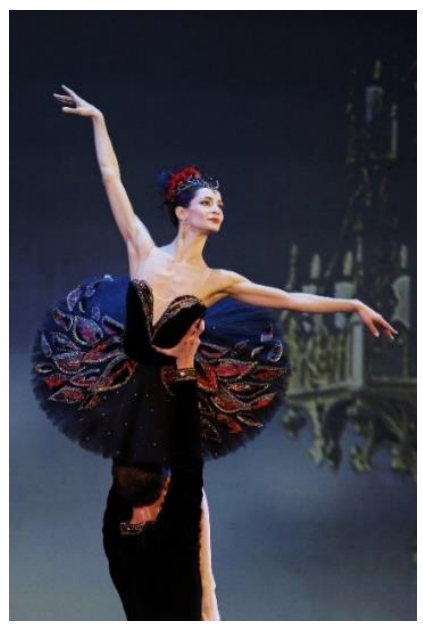

Photo 41

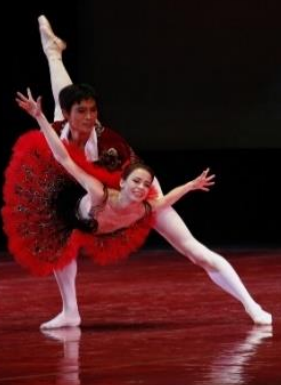

Photo 39

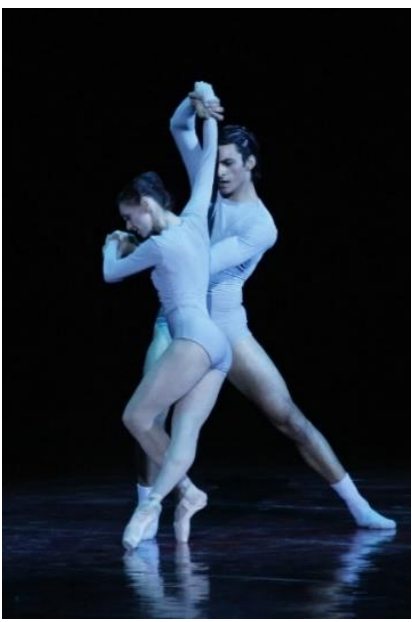

Photo 42

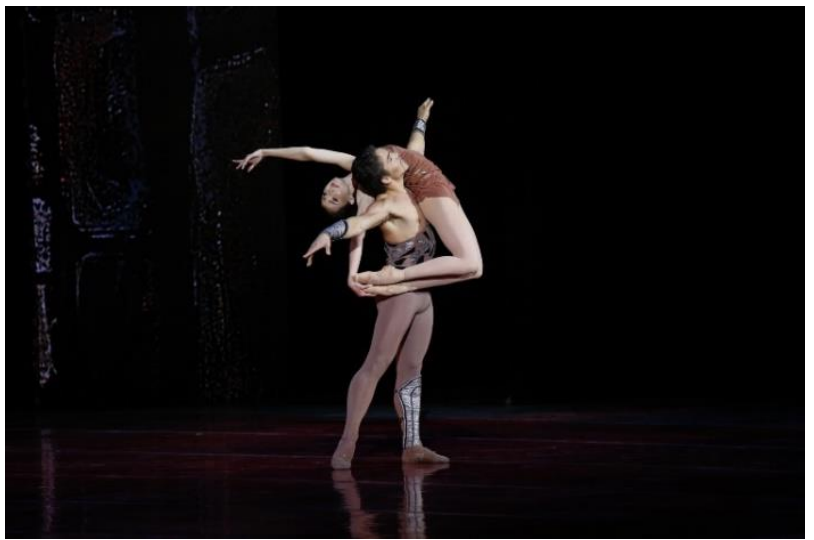

Photo 43

And, of course, this is the Summer Ballet Seasons festival with classical performances from very different ballet theatres. Especially ballet "Giselle" (Photo 4449) performed by Art-DA Theatre with invited soloists of the French theatre Grand Opera that let me get to know French dancers Eloise Bourdon and Jeromy-Lou Coeur. I do not presume to judge the art of execution, as I am not ballet critic, but I can say that I really liked their party from the emotional point of view. Especially women's party with Eloise Bourdon. 


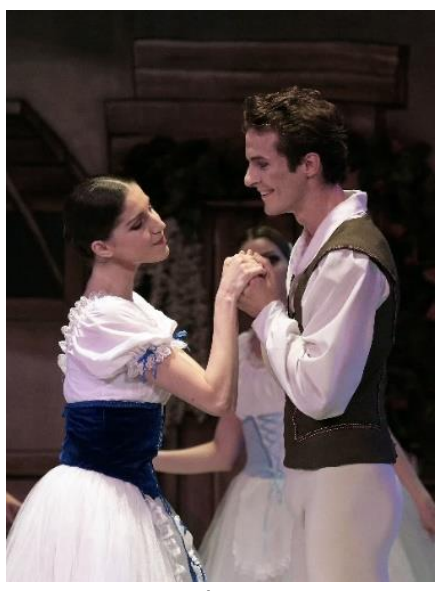

Photo 44

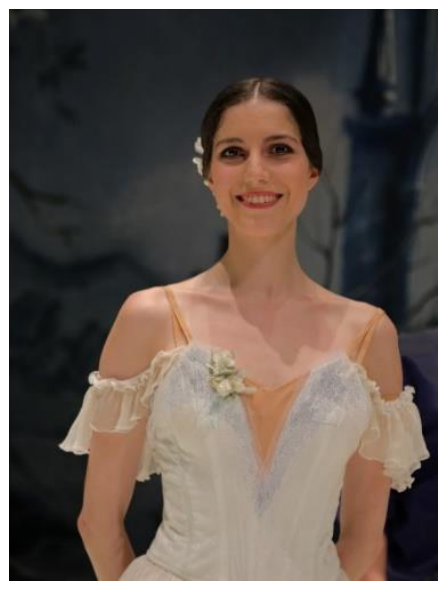

Photo 45

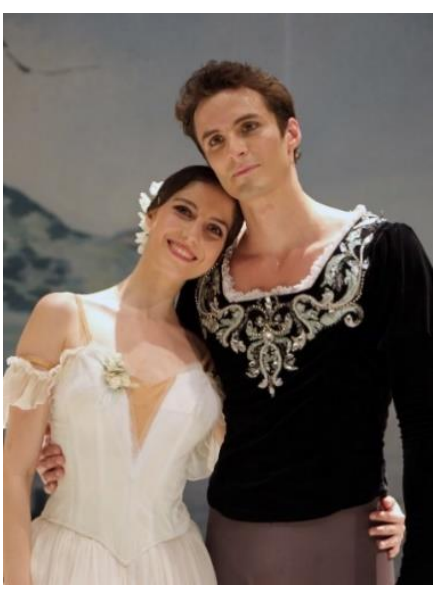

Photo 46

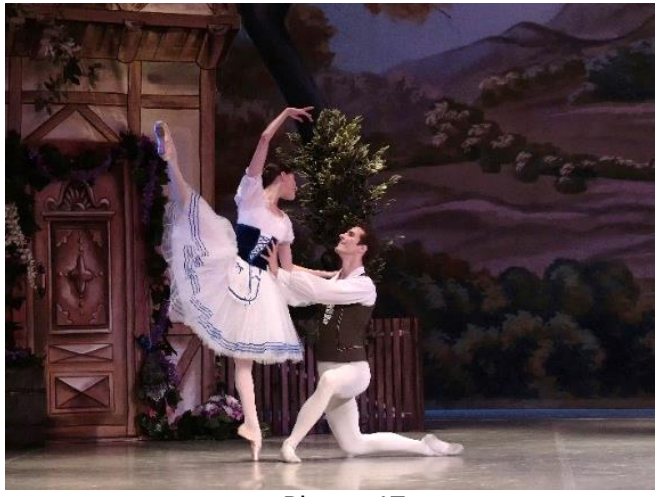

Photo 47

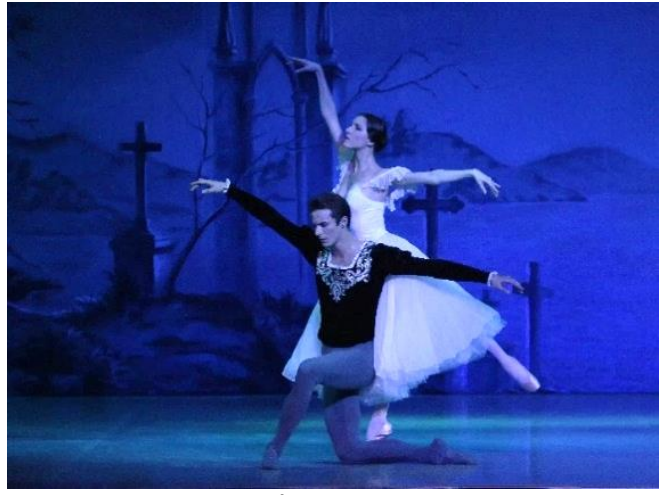

Photo 48

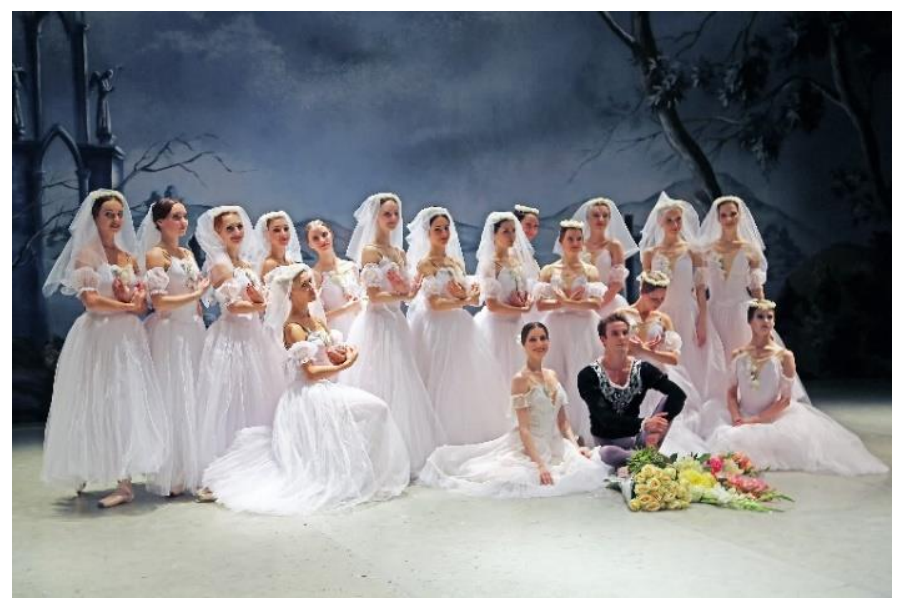

Photo 49

Classic performances "Bayadere" (Photo 50-51), "Sleeping Beauty", "Swan Lake" (Photo 52-55), "The Nutcracker" (Photo 56) by National Classical Ballet remembered with its beautiful costumes and warm reception of auditorium. 


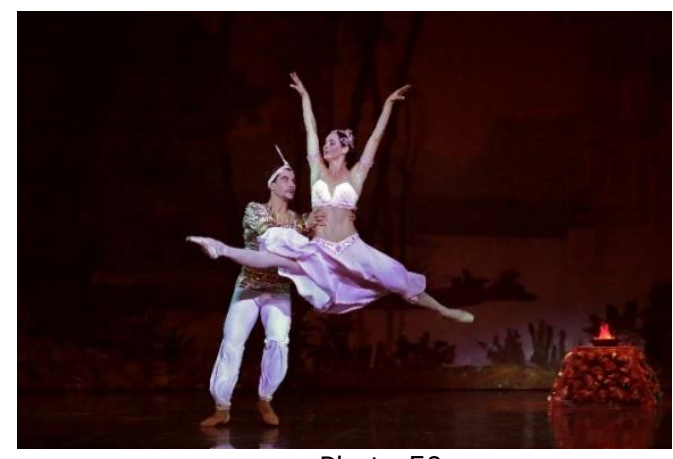

Photo 50

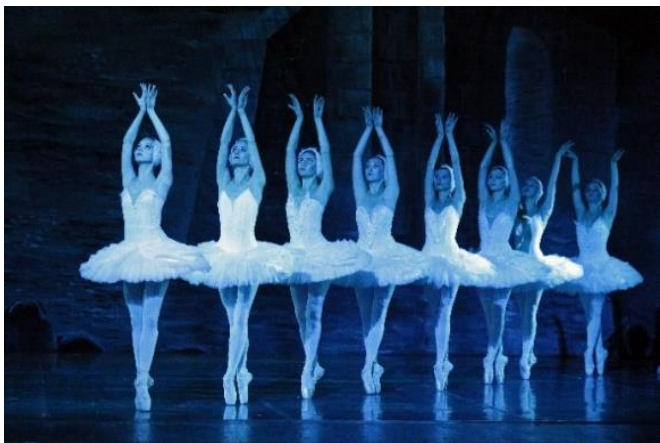

Photo 52

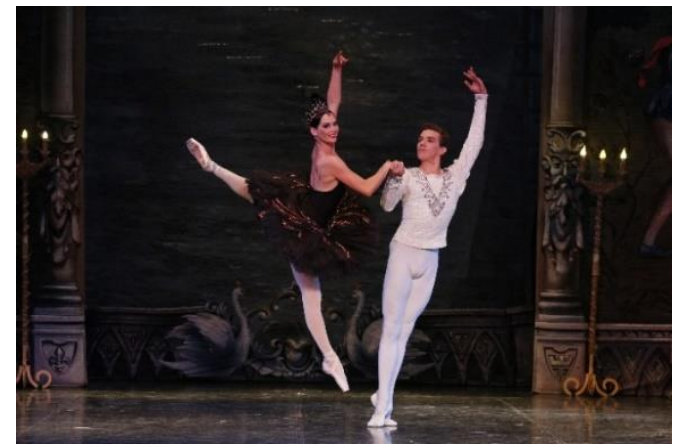

Photo 54

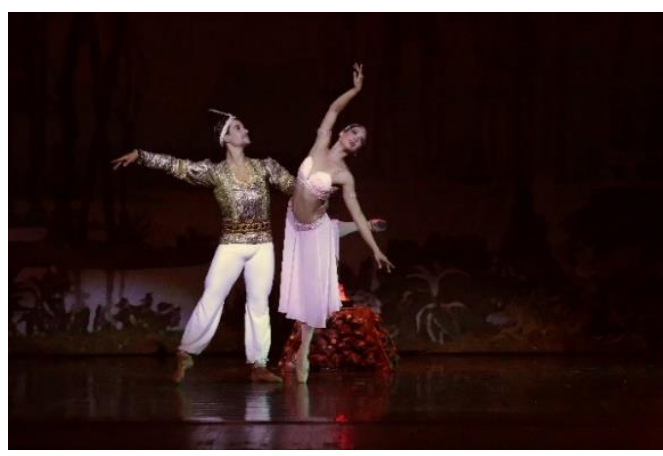

Photo 51

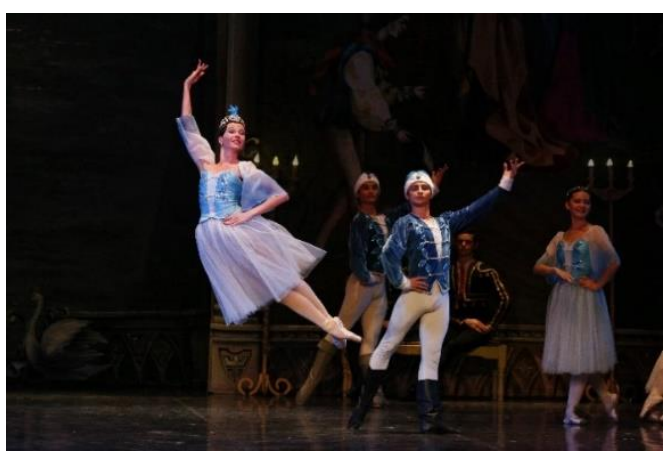

Photo 53

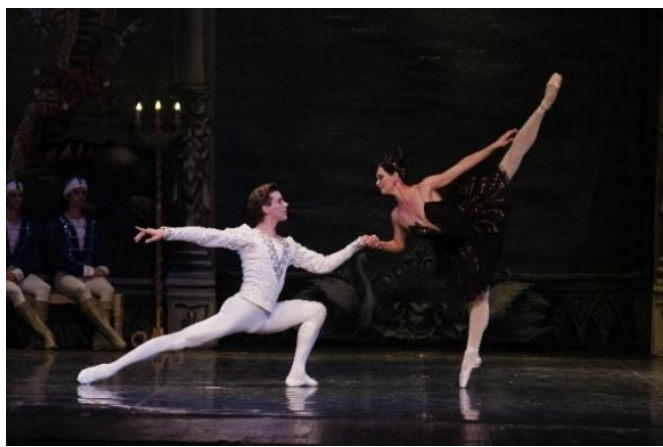

Photo 55

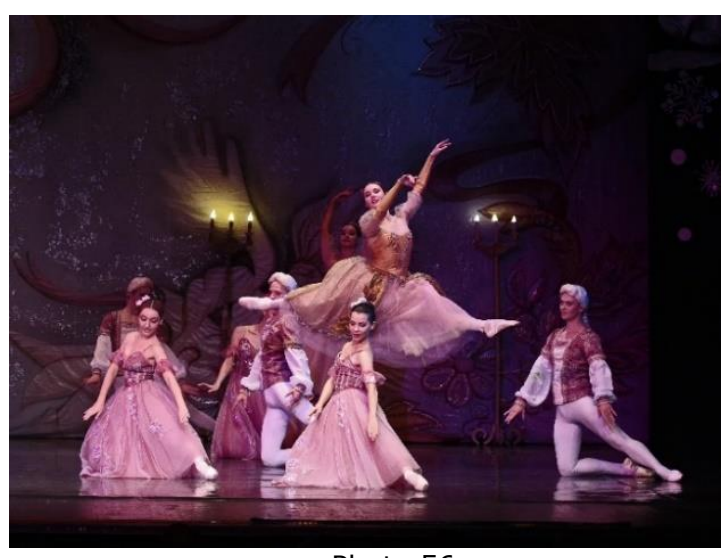

Photo 56

(C)ICS. Journal of Digital Art \& Humanities, Vol.1, Iss. 1, Oct 2020 
Met with a rather large range of the theatres and performances (classic as well as modern) I am still continue internal dispute with myself, what is direction number one in my work. It seems to me that such choice does not possible definitely, because it is impossible to compare non-comparable things. I think that both directions will be present in my practice in nearest further, because there are many wonderful things that I was inspired for new meeting with theatres and for the new shooting. It is absolutely certain that at this moment I want to capture the beauty of the art of the dance and show this to the world. There are many other interesting moments and subject matter in the ballet to consider in detail of course. However, as for me the topic of beauty in ballet is on the first place. Although it is possible that in the future, I will be touching other topics in ballet photos.

\section{Classic and modern ballet in terms of the photographer}

Classic and modern ballet in terms of the photographer point of view differ greatly. Classical ballet subject to certain laws. All of motion usually predictable. Music in this case, the best hint. If you have the minimum music education in addition to all thigs you already have (and I once was engaged in music with a teacher), the success for you almost guaranteed in this case. You just need to learn to read the language of the classical dance and to understand the construction of phrases and dialogue between the artists. Learn how to catch culmination moments, because most often they create those most memorable accents in dance, catching that you get excellent frames. Shooting the classical ballet, I never shot with the series frames, as do some photographers. I think this is meaningless, because camera will not be able to catch the best moment that you need and want to capture. In this case, if this happens, it is most likely it will be a fluke. At the same time if near you will be professional photographer, he caught the best moment, and you will be behind him or be ahead him onto some seconds. Therefore, his shot will be always better than yours. So, I continue to learn how to feel music and dance, that do not shoot everything and find then something right between you frames. I think that if you understood all of these things and feel that you can understand what time it is necessary to press the shutter to get the most beautiful frame. I am sure that I am on the right way, and that over time will be able to understand the language of dance even better.

An interesting point in my practice, which support me that I am already achieve some level in ballet photography. I shot one ballet-gala with well-known photographer. Sometime later, I accidentally saw his pictures in social networks. My best shots absolutely repeat all those moments that fixed master of ballet photos. For me it was kind of assessment of my results.

Why do I like to shoot a modern ballet? I like it because it is much more difficult to capture the right moment and when to press shutter. Sometimes music and choreography movements can be so unpredictable that you cannot catch those moments that you see on the stage. Perhaps I still lack a sense of the language of modern choreography. Probably the easiest option when you shooting modern ballet it is when artists danced in pointe shoes. In this case there many elements from the classical ballet. In this case it is little easier to shoot. Not all the moments are subject to here classic laws and therefore there is still enough extensive space for the photographer to take a beautiful shot.

If we look contemporary ballet not in the pointe shoes, then everything is complicated by many times. It is still quite difficult for me to catch the right moment. To get an excellent photo of modern ballet much more difficult than took the beautiful video. Because when you look all continuous video stream, when one pose or scene organically replaced by the other, that whole video stream is obtained more interesting because you do not fix every single moment. However, if for example, decompose this video stream onto single frames, then there will be very few ideal moments from the point of view of photography. These are the moments photographer must see and capture. What concerns me is only one opportunity to catch a beautiful frame, it is my own common sense of what I see, hear and feel. The 
complexity of the moment that it is necessary to evaluate and act almost at the same time.

More alternatively, it is pre-view performance or at least its rehearsal, remember moments that you like and try to catch them at follow-shooting.

Maybe that is why in my practice much more shooting of modern ballet performance than classic ballets. I wonder to capture a complex choreography of the performance in his best moments.

In this case, I miss all other features of ballet shooting - the presence of the right light, beautiful composition, interesting angle, etc. and concentrate only on the main - in fact on the move. It is movement - its beauty, tenderness, elegance, dynamics, force energy, soul dancer, I want to pass through photos of dance and ballet. I want to learn how to easily read the language of dance and speak this language by means of photography to show all people as fine this art of dance.

\section{A bit of technology shooting and photo post processing}

Speaking of dance photographing let pay attention to some technical aspects of this type of photography.

Let's start with an equipment that I use for shooting in the theatre - I have a digital full-size camera Canon 5D Mark III with two lenses Canon EF 100-400Mm F/4,55,6L IS USM and Canon 24-105 MM F/4L IS USM. You need telephoto zoom lens for shooting with the far distance, somewhere starting from 20th row in the theatre. It allows you to take as local scene and portrait shot. Canon 24-105m F/4L IS USM lens it is my second lens. I use it if I can shoot from the first row in auditorium hall or behind the scene.

Also, it is essential for shooting directly on the stage after the performance. It is necessary to say that I have quite specific lenses set that was formed and used for landscape photography during my travel. These two lenses completely satisfied me in the theatre too. Although sometimes it is not enough the aperture. Sometimes when shooting dark scenes, you need lens with minimal aperture. I think that in the nearest future I will add to my arsenal another lens Canon EF 70-200m F/ 2,8L ISII USM.

Specific of the ballet shooting on the stage is that you need to use high ISO to get a quality image and short exposures shutter to avoid the effect of lubrication images, particularly it concerned feet.

If concern the methods for shooting, I said already that not use serial frame. But sometimes can to the use some art techniques, such as multiple exposure. I use this method more often on the performances that I have shooting the second time. I can say at once that in this case, not all images are obtained the ideal quality and interesting, only some of them and the therefore you have physically less time for shooting the performance just technical reasons, because in this case, still have time to merge frame within the camera. Moreover, you can skip beautiful frame. I can also to say that I used multiple exposure more often when shooting modern ballets or on the ballet-gala, when the artists dance solo and very rarely on the classic performances.

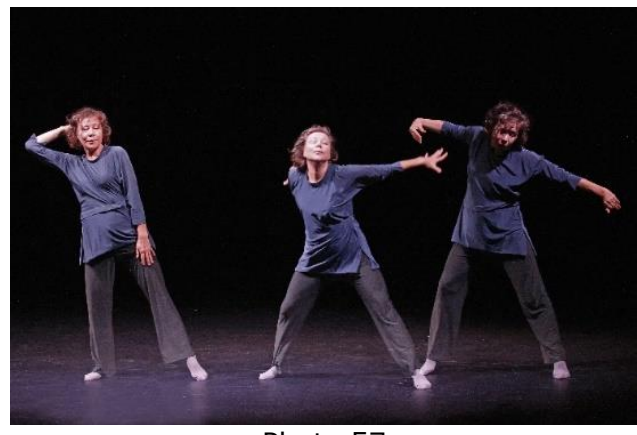

Photo 57

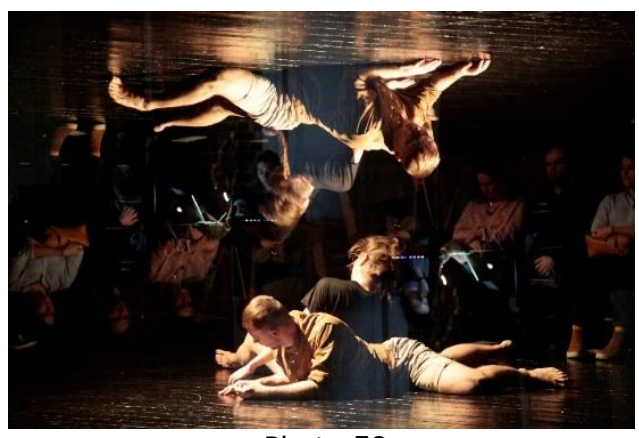

Photo 58 


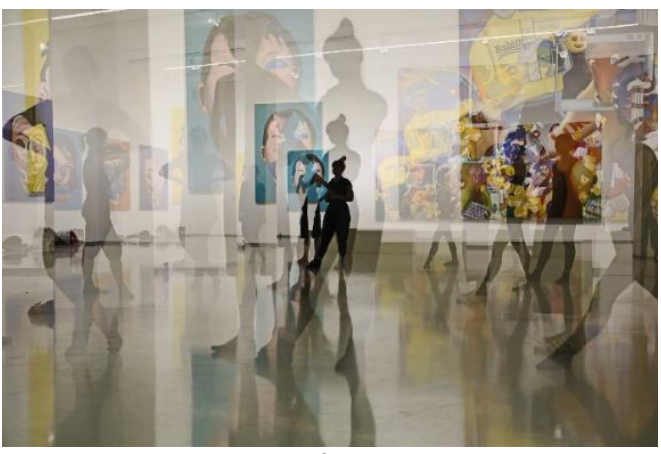

Photo 59

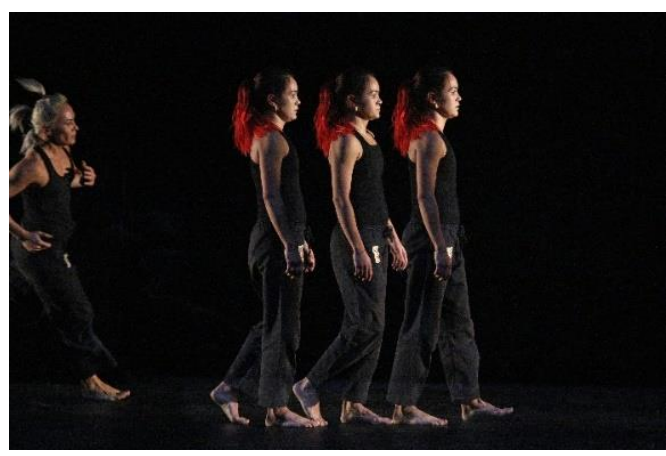

Photo 60

I can also say that I do not alien to the use of opportunities of photo editor Photoshop to form an interesting picture. Often such images can be attributed not just to the stage photos but also probably to the art photos. Below are examples of such images.

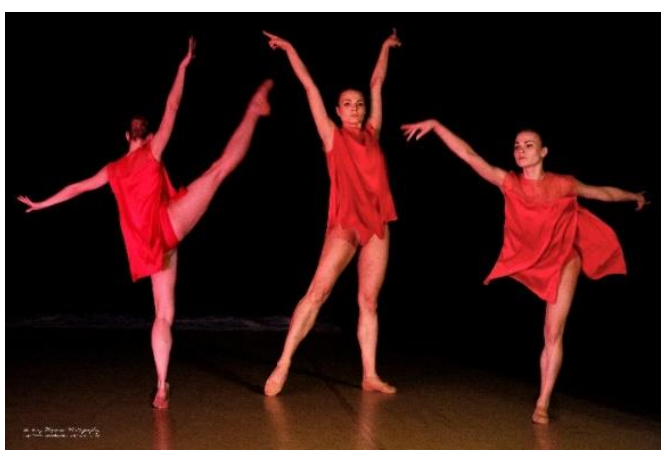

Photo 61

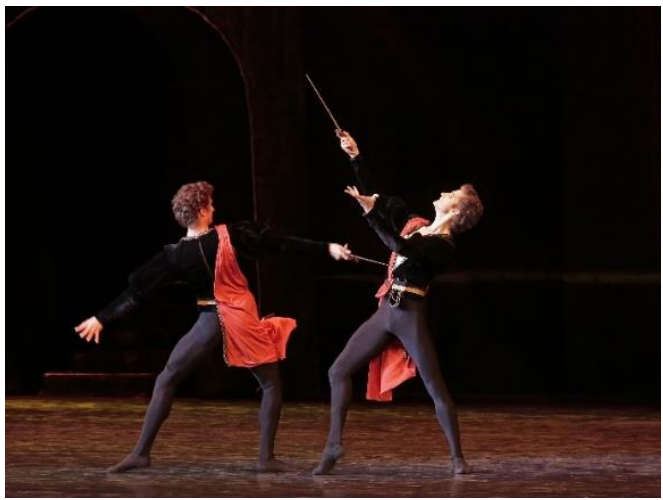

Photo 63

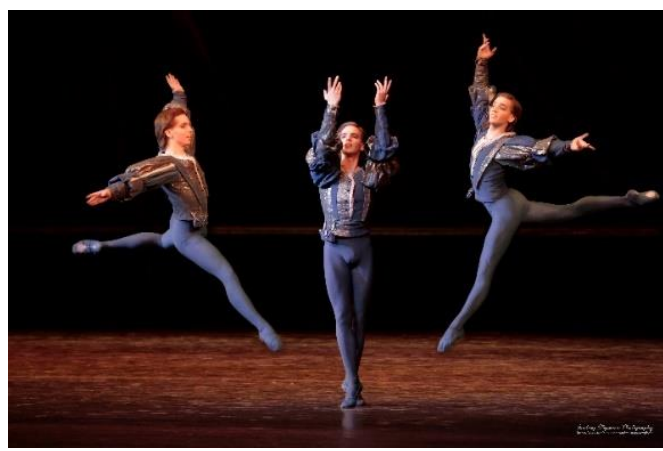

Photo 62

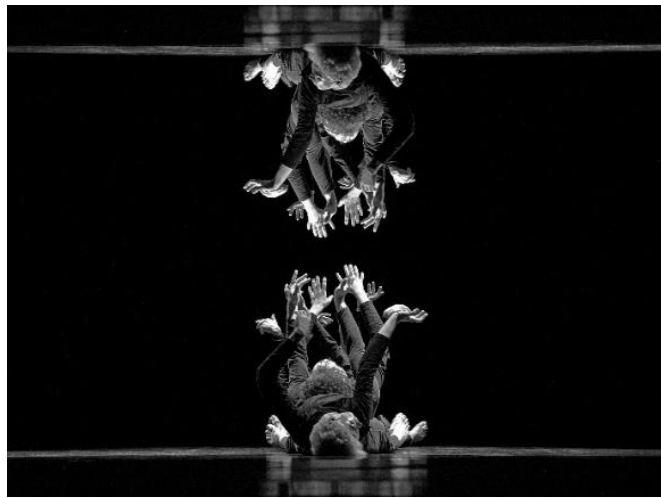

Photo 64

\section{For what or for whom to shoot a ballet}

For what or for whom to shoot a ballet, if it has very limited target audience? When answering to this question, it is possible to say the following that is for me there are several criteria why I do this. Firstly, I realized that to me it is just I like do that. Any photographer shoots for himself first, unless if it is not commercial shooting. It gives me an aesthetic pleasure to see a beautiful and interesting ballet, just as well as, for example, to see a beautiful nature, when traveling or, for example, just look at the beautiful bouquet of flowers. This is also a kind of bouquet only in motion as the flowers of the field in the wind. 
For me no one has been cancelled thesis "beauty will save the world", I want to believe it. Moreover, I know that it is necessary not only to me, but also to the other people. There are many fans of ballet in the social networks. In our life, there are people who like ballet so much that they learned in ballet studio, play together with other unprofessional and sometimes professional actors in the "home" ballet performance. They just go to watch ballet, as some other people go watch football. Not long ago I recently met a man who is real ballet lover. As I understand he goes on almost all new performances and ballets premiere, knows many actors and choreographers. Moreover, as far as I understand he is not alone.

I want to shoot ballet for that manner so that the peoples, when they saw my photos, wanted to go on the performance and see it live on the stage. I think that the beautiful art of dance can only be fully felt, understood and appreciated only on the stage.

Starting to shoot ballet, I discovered a lot of new ballet theatres, which produce their performances and find their audience. In this regard, it seems to me that a variety of ballet festivals play very important role. They are very different and each have their fans. For example, the "Summer ballet seasons" collect full rooms in Moscow during all summer for 19 years.

Share beauty with other it is just simply a nice. I have many ballet publications in social networks. There it is own constant audience and it is slowly growing all the time. There I can communicate with some ballet actors. For some reason I always thought that, this is a much-closed people and that this world almost completely closed for "external" people, including new photographers. However, it was a wrong perception of them. I have appeared very nice and responsive friends who helped me to learn and understand the ballet. Taught me fixed on the right moments, helped me professionally understand and see the dance. I am very grateful to these people.

I think that after the completion of the history of epidemic COVID-19, I will be able to do next exhibition for my audience. Let it will be very limited by the number of my fans, but I still waiting for a meeting them. I have already the proposal to make my next exhibition of my ballet photos a long time ago. It will be my second exhibition in the Financial University.

\section{References:}

1. "Catch the air in the lens ..." - about the Masters of ballet and fashion photography, La Personne, 2017/09/25, https://www.lapersonne.com/post/famous-ballet-fashion-phographer/. Last accessed 2020/08/28.

2. Top-5 Russian ballet photographers, Ballet 24, 2018/04/01, http://balet24.ru/?p=10136 Last accessed 2020/08/28.

3. Top-5 foreign ballet photographers, Ballet $24,2018 / 01 / 14$, http://balet24.ru/?p=5664. Last accessed 2020/08/28.

4. Open rehearsal joint program "Pas de de on the fingers and for the fingers" Bolshoi Theatre prima-ballerina Svetlana Zakharova and violinist Vadim Repin, Kommersant Photo, 2019/12/21, https://kommersant.ru/photo/category_in/182613. Last accessed 2020/08/28.

5. The Kremlin Ballet Theatre showed S.S.Prokofiev's "Romeo and Juliet" on the stage of Kremlin Palace, Kommersant Photo, 2020/02/28, https://kommersant.ru/photo/category_in/183568. Last accessed 2020/09/09.

6. Diana Vishneva's show "Dreams of The Sleeping Beauty", Kommersant Photo, 2019/09/20, https://kommersant.ru/photo/category_in/181278. Last accessed 2020/09/09.

7. Ballet "Little Red Riding Hood." Andrey Stepanov photo gallery, Dozado Dance Magazine, 2020/01/09, http://dozado.ru/fotogallery-stepanov-krasnayashapochka/. Last accessed $2020 / 08 / 28$.

8. Ballet stars in the Kremlin: "Maris Liepa. With love", "Window to Moscow", http://oknovmoskvu.ru/teatr1/news_post/zvezdy-baleta-v-kremle-maris-liepa-s-lyubovyu /, 2020/01/05. Last accessed 2020/08/28.

9. Romantic ballet. Andrey Stepanov photo gallery, Dozado Dance Magazine, 2020/06/08 http://dozado.ru/fotogallery-astepanov-feb20/. Last accessed 2020/08/28.

10. Miles Aldridge in Moscow: A taste of colours and illusion of gloss, Window to Moscow, 2019/12/15, http://oknovmoskvu.ru/vistavki/news_post/majlz-oldridzh-v-moskve-vkus-cvetai-illyuzii-glyanca. Last accessed 2020/08/28. 
11. This direction burst into my work completely unexpectedly, Svetlana Poliskaya, Andrey Stepanov. Dozado dance magazine, 2019/09/17, http://dozado.ru/andreystepanov2019/. Last accessed 2020/08/28.

12. Personal Facebook account https://www.facebook.com/andreyistepanov. Last accessed 2020/09/09.

13. Personal Facebook page https://www.facebook.com/andreystepanovphoto. Last accessed 2020/09/09.

14. Personal Instagram account https://www.instagram.com/andrey.ist. Last accessed 2020/09/09.

15. The Premiere of one-act ballets "The Death and the Maiden" and "Second Cast". Andrey Stepanov photo gallery, Dozado Dance Magazine, 2020/02/04, http://dozado.ru/baletmoscowgallery-andreystepanov/. Last accessed 2020/08/28. 